\title{
INDENTIFIKASI POLA AKSARA ARAB MELAYU DENGAN JARINGAN SYARAF TIRUAN CONVOLUTIONAL NEURAL NETWORK (CNN)
}

\author{
Budi Yanto ${ }^{1}$, Basorudin ${ }^{2}$, Jufri ${ }^{3}$, B. Herawan Hayadi ${ }^{4}$ \\ 1,2,3 Universitas Pasir Pengaraian, Indonesia \\ ${ }^{4}$ Universitas Ibnu Sina, Indonesia
}

Email: ${ }^{1}$ budiyantost@gmail.com, $\underline{2}$ basorudinupp@gmail.com, ${ }^{3}$ jufrirokan@gmail.com ${ }^{4}$ b.herawan.hayadi@gmail.com

\section{Article Info}

Article history:

Received, 20/11/2020

Revised, 25/11/2020

Accepted, 27/11/2020

\section{Kata Kunci:}

Arab Melayu, Pengenalan Pola Aksara, Neural Convolutional Network

\section{ABSTRAK}

Provinsi Riau memiliki aksara Arab Melayu sebagai warisan budaya tradisional aksara kuno yang patut dilestarikan, aksara ini diadaptasi dari tulisan Arab. Aksara dari tulisan Arab Melayu ini memiliki bentuk yang unik yang berbeda dengan adaptasi tulisan Arab aslinya, yang pembacaanya dalam kombinasi rangkaian huruf membentuk artian bahasa latin sebagai pengantar bahasa sehari-hari masyarakat Melayu Riau pada zama kerajaan terdahulu. Tulisan Arab Melayu menjadi pengantar Muatan Lokal Bahasa tradisional dalam sekolah-sekolah. Untuk menumbuhkan rasa cinta dalam melestarikan budaya, untuk mengenali pola tulisan Aksara ketika dituliskan dalam kertas, dibuatlah suatu basis pengetahuan dengan memamfaatkan software Matlab dengan menerapkan algoritma jaringan syaraf tiruan Convolutioal Neural Network (CNN) yang mampu mengenali pola aksara tulisan dengan baik. Hasil inputan citra berupa tulisan tangan yang dituliskan di kertas kemudian di scanner dalam bentuk format gambar JPEG. Pengujian dilakukan pada empat aksara arab melayu yaitu alif, ha, la, kho dan nun. Hasil dari training untuk huruf alif (a) epochnya didapat 98 dari 100 iteration dengan lama training 3 detik, selanjutnya di validation perfomance dengan hasil 0.25013 pada epoch 92 dari 98 epoch untuk gradient huruf dengan nilai 0.0071991 pada epoch 98 selanjutnya di ekstra menghasilkan nilai akurasi 0.6548 yang menyatakan kesesuaian hasilnya yang benar karena mendekati huruf aksara alif. Pada proses train inputan huruf kho didapat epoch 80 dari 100 iteration dengan proses training selama 3 detik, validation perfomance 0.25153 pada epoch 74 dari 80 epoch untuk check validation dengan nilai 0.0011682 pada epoch 80 selanjutnya di ekstrasi didapatkan nilai ekstrasi 0.9326 dinyatakan nilai tersebut salah. karena hasil dari ekstrasi menghasilkan citra yang tidak mendekati ke huruf aksara kho. Untuk itu dibuatlah suatu penelitian bagaimana sistem dapat mengenali pola tulisan Arab Melayu dengan metode Convolutioal Neural Network (CNN) karena sangat bagus dalam mengeskraksi fitur pola citra gambar dengan nilai akurasi $4,12 \%$ dari 10 sample pola citra yang telah di inputkan. Dengan pengenalan pola citra gambar dari ekstraksi fitur scan aksara Arab Melayu dapat membantu temuan tulisan Aksara Arab Melayu kuno sebagai pembelajaran morfologi keabsahan abstraksi tulisan Aksara Arab Melayu ini secara baik

\section{ABSTRACT}

Keywords:

Malay Arabic, Patterns Recognation, Convolutional Neural Network
Riau province has Malay Arabic script as a traditional cultural heritage of ancient characters that should be preserved; this script is adapted from Arabic writing. This script from Malay Arabic has a unique form that is different from the original Arabic writing adaptation, which is read in a combination of letters forming latin meanings as an introduction to the everyday language of Riau Malay people in the earlier kingdom. Malay Arabic writing became an introduction to the local content of traditional languages in schools. To foster a love for preserving culture, in accordance with current technology that is able to recognize scripting patterns when written in paper, a knowledge base was created by using Matlab software by applying a convolutional Neural Network (CNN) artificial neural network algorithm capable of recognizing script patterns well. The result of image input in the form of handwriting written on paper then in the scanner in the form of JPEG image format. Testing was carried out on four Arabic Malay 
characters namely alif, ha, la, kho and nun. The result of training for the letter alif (a) epoch is obtained 98 out of 100 iterations with a training length of 3 seconds, furthermore, in validation performance with a result of 0.25013 on epoch 92 of 98 epoch for gradient letters with a value of 0.0071991 on the next epoch 98 in the extras produces an accuracy value of 0.6548 which states the correct result accordingness because it is close to the alif script. In the process of train input the letter kho obtained epoch 80 out of 100 iterations with a training process for 3 seconds, validation performance 0.25153 on epoch 74 out of 80 epoch for check validation with a value of 0.0011682 on the next epoch 80 in the extras obtained an extra value of 0.9326 stated the value is incorrect. Because the result of the extras results in an image that does not come close to the kho letter. Therefore, a study of how the system can recognize Malay Arabic writing patterns with the Convolutional Neural Network (CNN) method because it is very good at identifying image pattern features with an accuracy value of $4.12 \%$ of the 10 sample image patterns that have been inputted. With the introduction of imagery patterns from the extraction of features scanned Malay Arabic characters can help the findings of ancient Malay Arabic script as morphological learning of the validity of abstraction of Malay Arabic script is good

This is an open access article under the CC BY-SAlicense.

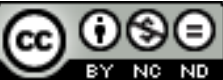

\section{Penulis Korespondensi:}

Jojo,

Program Studi Informatika,

Universitas Komputer Indonesia,

Email: jojo@gmail.com

\section{PENDAHULUAN}

Bahasa adalah sebagai pengantar komunikasi antar satu dengan yang lainnya, dan setiap daerah yang ada di Indonesia memiliki keberagaman bahasa sebagai pengantar komunikasi, dari bahasa ini tentunya ada tulisan yang dituliskan sebagai pengantar penguat dari maksud bahasa lisan yang di ucapkan. Setiap tulisan itu memiliki makna yang berbeda, sesuai juga dengan pengucapannya. Dari tulisan ini dikenal dengan aksara. Karena kekayaan Indonesia yang memiliki beragam bahasa sebagai pengantar komunikasi, tentunya juga memiliki aksara tulisan yang beragam pula. Seperti bahasa Melayu sebagai bahasa induk awal datangnya bahasa Indonesia yang memiliki aksara Arab Melayu, Aksara Arab melayu ini di sadur dari bahasa Arab dengan memiliki ke unikan tersendiri baik itu ucapan dan pembacaannya, akan tetapi untuk penulisannya masih mengikuti bahasa Arab.[1]

Aksara Arab Melayu merupakan warisan leluhur pada rintisan suku melayu yang terkenal pola tulisannya dari zaman dahulu hingga zaman sekarang. Aksara Arab melayu ini merupakan ciri khas budaya lokal Provinsi Riau. Pada sekolah-sekolah dan perguruan tinggi di Provinsi Riau di wajibkan untuk mengenal dan memahami bahasa arab melayu. Hal ini karena budaya arab melayu dari datanganya kerajaan melayu riau merupakan pelopor dari adanya bahasa arab melayu ini, aksara arab melayu yang bercirikan Islam, sesuai dengan masyarakat asli riau yang masih kental akan budaya islami, sehingga setiap kegiatan dan corak dari bangunan mengikuti budaya arab. Tampak dari bangunan, tulisan, pakaian yang bercirikan arab. Rokan Hulu yang terkenal dengan Negeri Seribu Suluk yang sangat menjunjung tinggi nilai kebudayaan yang bernuansa Islami, terlihat dari berbagai kegiatan yang mengikuti budaya arab, termasuk saduran dari bahasa yaitu bahasa arab melayu, sebagai pemersatu untuk komunikasi, untuk aksara dalam pelajaran serta kajian arab, banyak di tuliskan dalam lembaran dengan menggunakan aksara arab melayu. Di sekolah agama di Rokan Hulu diwajibkan adanya muatana lokal untuk pelajaran Arab yang di ajarkan di sekolah-sekolah dan Perguruan Tinggi juga ada Mata Kuliah Pelajaran Budaya Melayu. [2].

Bapak Drs. Achmad, Msi selaku Bupati di Kabupaten Rokan Hulu pada tahun 2016 telah memwajibkan pegawainya untuk bisa menulis dan berpidato dengan tulisan aksara Arab Melayu, sehingga setiap sekolah yang mulai dari jenjang SD sampai SLTA wajib mengenal aksaran tulisan aksara Arab Melayu sebagai cagar budaya nasional yang patut dilestarikan. Faktor yang mempengaruhi minat baca dan mengenal tulisan aksara arab melayu adalah keterbatasan media yang offline dan online yang ada saat ini. [3]

Permasalahan yang terjadi karena keterbatasan media untuk pengenalan pola aksara yang lebih jelas dan detail perbedaan aksara Arab Melayu yang akan diterjemahkan kedalam sistem informasi, maka di terapkan metode Convolutional Neural Network. Kemampuan dari metode adalah sangat baik dalam proses ekstraksi fitur pola citra gambar yang akan diterjemahkan dalam bentuk pola grayscale citra gambar. [4]

Pengenalan pola huruf arab melayu ini diterapkan dengan metode Convulation Neural Network (CNN) dengan huruf yang digunakan seperti contoh: huruf $\omega$, ketika kita masukkan huruf tersebut maka akan diekstraksi hurufnya sehingga menghasilkan output menjadi w. 
Metode ini sangat baik dalam pengenalan dan pendeteksian objek, berdasarkan penelitian yang dilakukan pada tahun 2012, bahwa Convolutional Neural Network (CNN) dalam melakukan pengenalan citra digital tingkat akurasi eksraksi citra gambar digital di dataset sangat baik [5]. Untuk itu dilakukanlah penelitian dalam pengenalan pola tulisan Aksara Arab Melayu dengan metode Convolutional Neural Network (CNN) yang dilakukan secara offline dengan menggunakan tool matlab.

Convolutional Neural Network (CNN) dengan pendektan Jaringan Syaraf Tiruan merupakan bahagian dari Metode Deep learning (DL) dengan kemampuan untuk mengenali objek di citra image digital dengan bentuk struktur dari input (masukan) feature learning (proses ekstrasi fitur) dan output (keluaran) yang dapat menterjemahan hasil citra digital gambar dengan jelas.[6] Untuk mendapatkan hasil yang bagus maka diperlukan hardware dengan spesifikasi yang bagus, untuk pengenalan grafik gambar yang berkualitas, digunakan Graphical Procesing Unit (GPU). Dengan pengenalan pola Aksara Arab Melayu ini diharapkan dapat sebagai pembelajaran untuk lebih detail mengenal morfologi dari Aksara Arab Melayu. Dengan inputan berupa tulisan Aksra Arab Melayu yang di Scan dijadikan format gambar digital JPG selanjutnya digunakan tool matlab untuk pengenalan pola dengan ekraksi fitur grayscale, dan algoritma Metode Convolutional Neural Network (CNN) untuk menentukan tingkat pendekatan akurasi gambar dari inputan tersebut

\section{METODE PENELITIAN}

Meetode penelitian yang dilakukan untuk mendapatkan hasil dari penelitian ini dilakukan dengan beberapa tahap: langkah pertama adalah studi literatur, dimana dialam mendapatkan informasi mengenai permasalahan yang akan diteliti dilakukan dengan mengumpulkan bacaan referensi sebagai pendukung melalui jurnal, paper dan buku bacaan terkait yang berhubungan dengan permasalahan. Sedangkan untuk pengembangannya perangkat lunak dengan menggunakan metode waterfall. Selanjutnya untuk pengujian dan penarikan kesimpulan

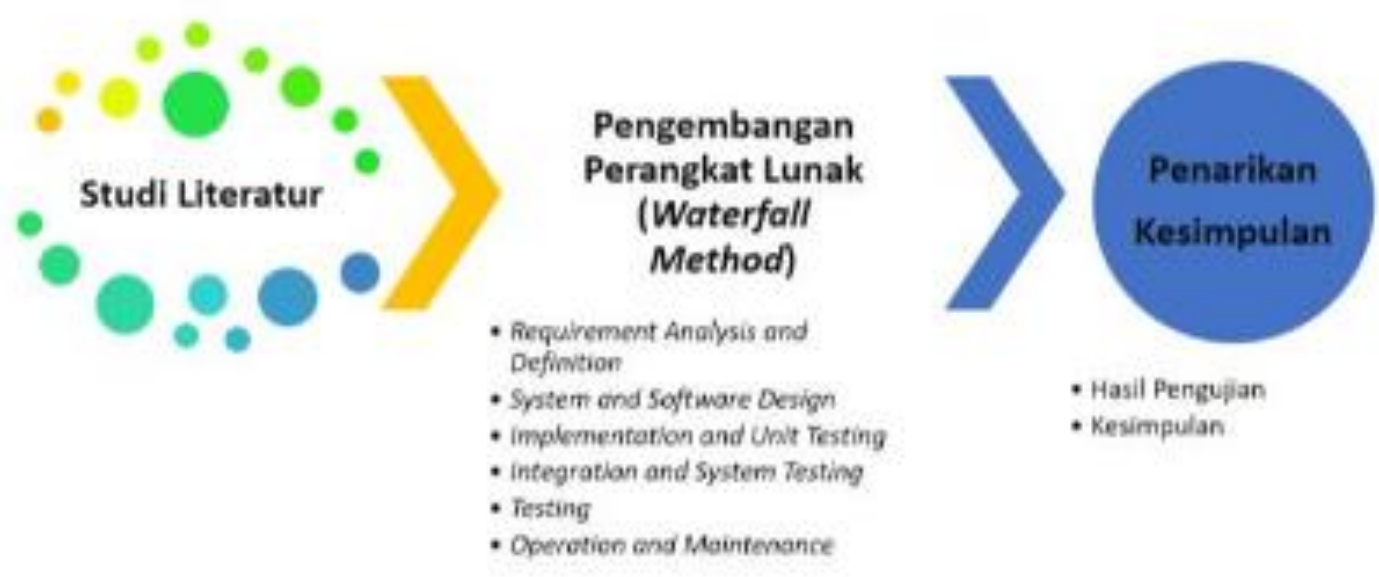

Gambar 1 Metode Penelitian

\section{HASIL DAN ANALISIS}

A. Aksra Arab MelayuAksara Arab Melayu adalah Tulisan dengan Aksara (Hijaiyah) yang disadur dari Aksara Arab. Merupakan sebagai bahasa pengantar Melayu Riau. Tulisannya sesuai dengan perkembangan dalam penyebaran Islam di Tanah Melayu yang menyebar ke suluruh Nusantara, dapat dilihat dari sejarah datangnya Kerajaan Islam - Melayu. Terutama dari kerajaan Siak Sri Indrapura yang memiliki struktur dan bangunan khas Arab, sampai dengan tulisan pada berkas-berkas perjanjian dan berita acara di kerajaan melekat dengan tulisan Arab Melayu. Pola tulisan Arab Melayu terdiri dari 36 karakter huruf yang terdiri dari 32 huruf hijaiyah arab dan 4 huruf lainnya sebagai tambahan. Huruf arab melayu ini memiliki konsonan yang mudah dibaca dan dimengerti dengan konsonan a,I,u. aksara arab melayu ini tidak memiliki baris atau garis harkat sebagai tanda ejaan baca yang terlihat seperti kitab gundul. [7] 
JSAI : Journal Scientific and Applied Informatics

Vol. 3, No. 3, November 2020, hal. 106-114

E-ISSN: 2614-3054; P-ISSN: 2614-3062, accredited by Kemenristekdikti, Sinta 5

\begin{tabular}{|c|c|}
\hline LATIN & $\begin{array}{l}\text { ARAB- } \\
\text { MELAYU }\end{array}$ \\
\hline A & 1 \\
\hline$B$ & ب \\
\hline C & ج \\
\hline D & 2 \\
\hline DL & ض \\
\hline$F$ & ن \\
\hline G & ] \\
\hline GH & $\dot{\varepsilon}$ \\
\hline H & $\tau$ \\
\hline$H$ & هـ \\
\hline I & ? \\
\hline K & 4 \\
\hline
\end{tabular}

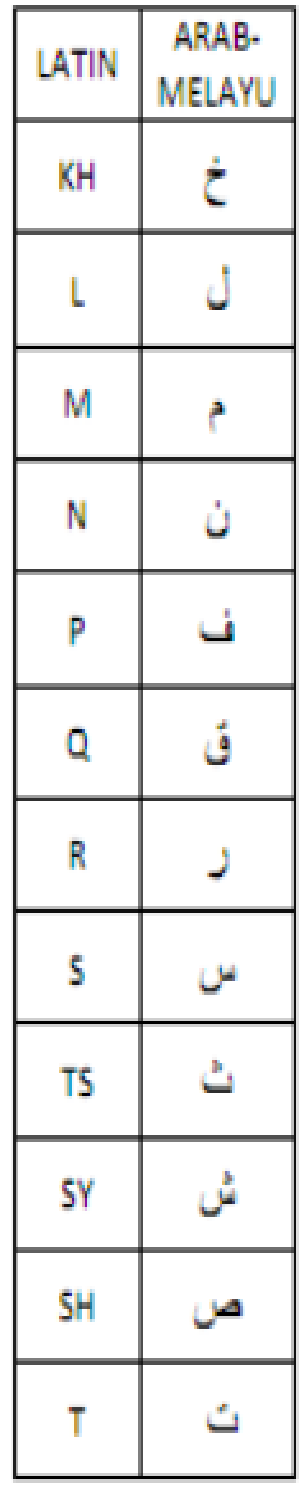

\begin{tabular}{|c|c|}
\hline LATIN & $\begin{array}{l}\text { ARAB- } \\
\text { MELAYU }\end{array}$ \\
\hline TH & b \\
\hline W & g \\
\hline$Y$ & ثي \\
\hline$z$ & j \\
\hline $\mathrm{DZ}$ & $j$ \\
\hline $\mathrm{ZH}$ & b \\
\hline $\mathrm{ZH}$ & b \\
\hline 'ain & $\varepsilon$ \\
\hline hamzah & 6 \\
\hline $\begin{array}{c}a^{\prime} \\
\text { Marbuthah }\end{array}$ & i \\
\hline NG & $\varepsilon$ \\
\hline NY & ن \\
\hline
\end{tabular}

Gambar 2. Aksara Arab Melayu

\section{B. Convolutional Neural Network (CNN)}

Merupakan suatu desain aristektur dengan data latih yang dilakukan dengan beberapa tahap. Masukan (input) dan pengeluaran (output) pada setiap yang terdiri dari kumpulan array disebut dengan feature map.

Proses pada tahapan arsitektur pertama ini adalah konvolusi. Hal ini memproses gambar huruf yang telah ditentukan pola hurufnya. Proses perhitungan jumlah karnel tergantung yang dipakai dari jumlah fitur yang dihasilkan pada pola tersebut. Pada tahapan berikutnya yaitu dengan fungsi aktivasi, biasanya menggunakan fungsi aktivasi relu, selanjutnya setelah keluar dari fungsi aktifasi tersebut, kemudian melalui fungsi pooling. Fungsi ini terbagi menjadi dua yaitu max pooling dan mean pooling. Arsitektur dari Metode Convolutional Neural Network dapat tergambar dibawah ini. [8]

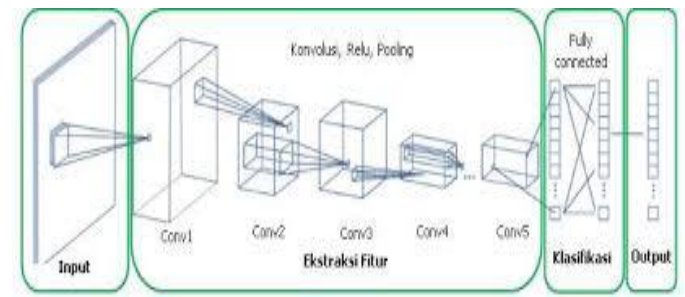

Gambar 3. Arsitektur CNN 
JSAI : Journal Scientific and Applied Informatics

Vol. 3, No. 3, November 2020, hal. 106-114

E-ISSN: 2614-3054; P-ISSN: 2614-3062, accredited by Kemenristekdikti, Sinta 5

DOI: 10.36085

Keterangan:

1. Convolutional Layer

Convolutional Layer adalah pada layer pertama ini adalah terdiri dari beberapa filter yang berfungsi untuk menterjemahkan citra digital sebagai proses masukan. Dapat didefenisikan dengan Rumus:

$$
s(t)=(x * t)(t)=\sum_{\alpha=-\infty}^{\infty}(\alpha) * w(t-\alpha)
$$

Keterangan :

$\mathrm{S}(\mathrm{t})$ : fungsi hasil operasi konvolusi

$\mathrm{X}$ : input

W : bobot (karnel)

Fungsi pada fungsi masukan $s(t)$ dengan nilai fungsi tunggal pada output menghasilan feature map. Untuk hasil terjemahan kedua w pada kernel $\mathrm{x}$ di filter menjadi 2 proses dimensi. Untuk operasi itu dituangkan dalam rumus operasi matemamatika sebagai operasi konvolusi. Sebagai berikut:

$$
\begin{gathered}
s(i, j)=s(i, j)=(k * i)(i, j)=\sum_{\infty} \sum_{\infty} I(i-m, j-n) K(m, n) \\
(k * i)(i, j)=(K * i)(i, j)=\sum_{\infty} \sum_{\infty} I(i+m, j+n) K(m, n)
\end{gathered}
$$

dari hasil penggabungan persamaan kedua rumus pada perhitungan konvolusi i,j mengahsilan sebuah piksel dari citra digital gambar. Konvolusi ini dilakukan dengan proses perkalian matriks pada cira dengan kernel i,j sehingga menghasilkan perhitungan luaran yaitu dot product.

2. $\quad$ Pooling Layer

Pooling Layer adalah suatu hasil pengurangan perhitungan matriks, dimana ada 2 jenis pooling yang digunakan yaitu max pooling dan average pooling.[9] . rata-rata yang di ambil adalah max pooling sebagai hasil nilai akurasi paling tinggi dari average pooling.[10]

3. fully connected layer

pada layer yang diambil dari neuron dilayer sebelumnya yaitu convolutional layer dengan max pooling layer di hubungkan dengan single neuron yang dimiliki.[11]

Dalam proses pengenalan huruf dengan tulisan tangan pada huruf arab melayu dengan menuliskan dikertas kemudian hasil tulisan huruf arab melayu tersebut di scan menggunakan scanner berbentuk jpg. Pengujian dilakukan dengan 4 pola huruf arab melayu. Hasil pengujian sistem dengan metode Convolutional Neural Network ( CNN) dapat dilihat melalui citra testing berisi pola pengenalan huruf arab melayu yang ditulis dengan tangan kemudian di scan, kolam keluaran merupakan hasil dari pengujian dengan sistem langkah berikut ini.

Pola huruf arab melayu alif ( a ) dengan MATLAB :

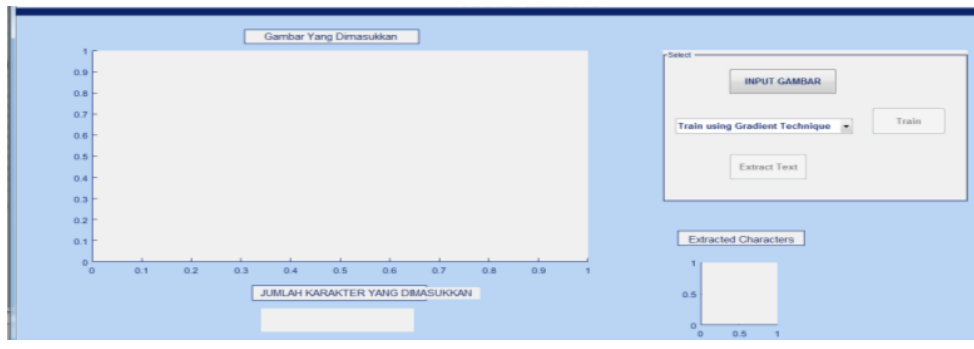

Gambar 3. Tampilan Utama Aplikasi

Pada tampilan ini memiliki beberap fungsi yaitu : tombol input gambar berfungsi untuk memasukkan gambar kedalam program, tombol train akan muncul ketika gambar sudah di inputkan kedalam program dan berfungsi untuk melatih atau train gambar yang sudah dimasukkan kedalam program. 
JSAI : Journal Scientific and Applied Informatics

Vol. 3, No. 3, November 2020, hal. 106-114

E-ISSN: 2614-3054; P-ISSN: 2614-3062, accredited by Kemenristekdikti, Sinta 5

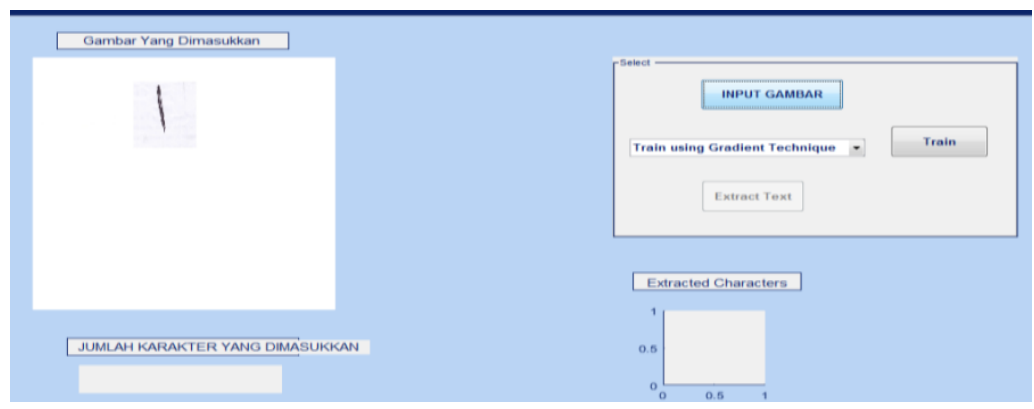

Gambar 4. Tampilan ketika gambar sudah di inputkan

Setelah di klik tombol input gambar maka gambar akan muncul di dalam aplikasi, kemudian gambar akan di train dengan mengklik tombol Train.

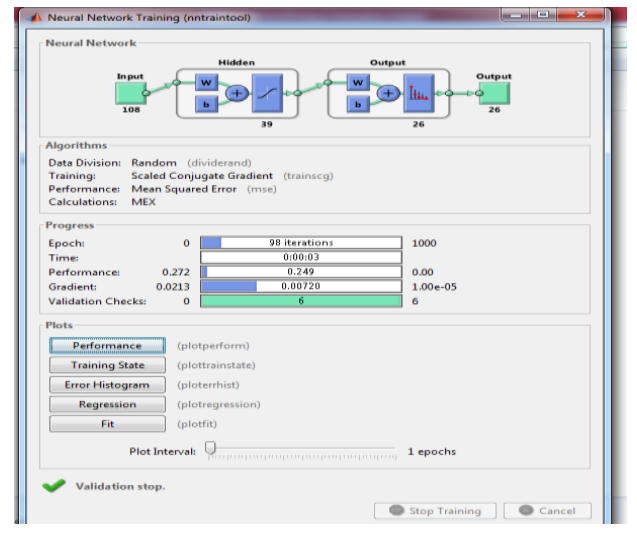

Gambar 5. Proses Training

Dari gambar di atas dapat diliat untuk huruf alif (a) untuk epoch nya didapat 98 dari 1000 iterations dan untuk lama proses training nya yaitu 3 detik. Setelah muncul layer training maka akan muncul hasil matriks dari gambar yang diinputkan ke dalam program untuk gambar matriknya dapat dilihat dibawah ini :

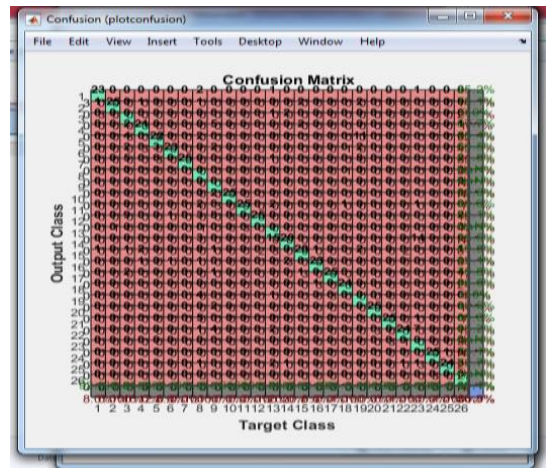

Gambar 6. Matriks

Untuk melihat validation performance dapat dilihat pada gambar dibawah:

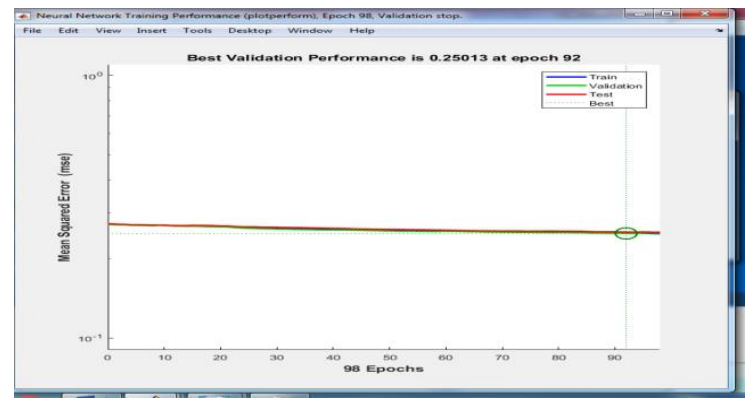

Gambar 7. Validation Performance 
JSAI : Journal Scientific and Applied Informatics

Vol. 3, No. 3, November 2020, hal. 106-114

E-ISSN: 2614-3054; P-ISSN: 2614-3062, accredited by Kemenristekdikti, Sinta 5

DOI: 10.36085

Dari gambar diatas untuk tingkat validation performance nya adalah 0.25013 pada epoch 92 dari 98 epoch. dan untuk check validation dapat di lihat pada gambar dibawah ini :

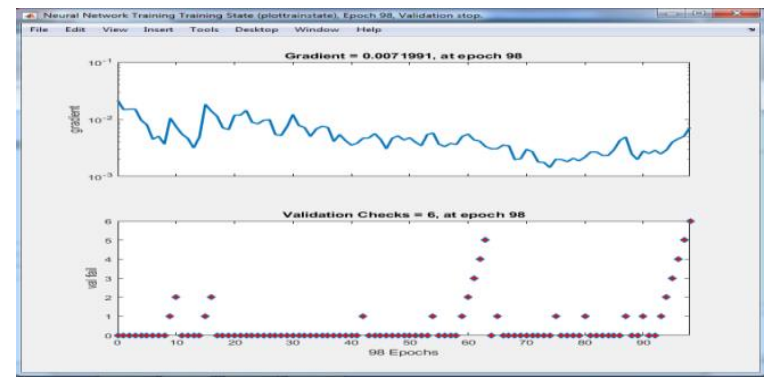

Gambar 8. Check Validation

Dari gambar diatas dapat disimpulkan bahwa untuk gradienthuruf tersebut adalah 0.0071991 terdapat pada epoch 98, dan untuk validation checks terdapat 6 pada epoch 98. Setelah didapat tingkat validation dan performance langkah selanjutnya adalah dengan menekan tombol ekstrak untuk mengektrak gambar yang telah dimasukkan kedalam program tersebut, untuk proses ektrak akan muncul beberapa layer sehingga setelah diekstrak maka akan muncul hasil dari ekstrak tersebut seperti gambar di bawah ini :

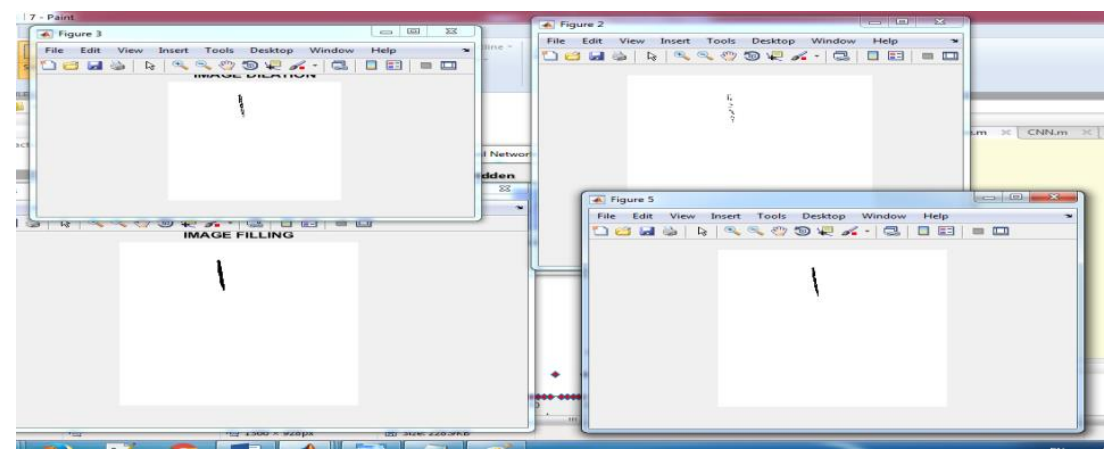

Gambar 9. Proses Ekstrak

Dari gambar layer figure 1 merupakan gambar yang di input kan kedalam program kemudian akan di proses sehingga muncul hasil ekstrak tersebut pada layer figure 5. Sehingga pada program akan tampil hasil output dari ekstrak tersebut seperti gambar dibawah ini :

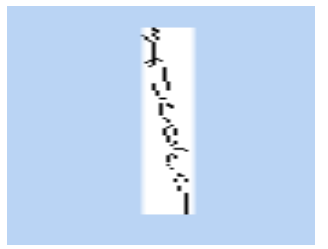

Gambar 10. Hasil Output

Setelah hasil output tampil maka program akan menampilkan tingkat akurasi dalam pengenalan pola tersebut, untuk hasil akurasi dapat dilihat pada gambar dibawah ini :

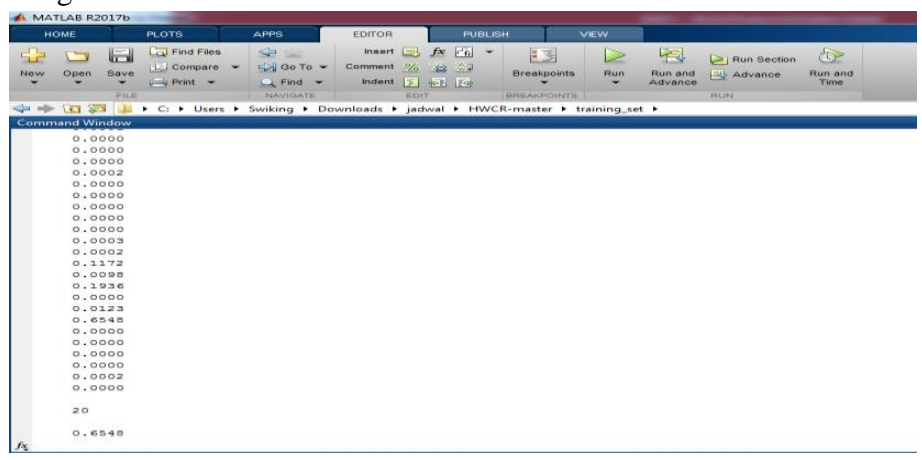

Gambar 11. Hasil Akurasi 
JSAI : Journal Scientific and Applied Informatics

Vol. 3, No. 3, November 2020, hal. 106-114

E-ISSN: 2614-3054; P-ISSN: 2614-3062, accredited by Kemenristekdikti, Sinta 5

DOI: 10.36085

Pada gambar diatas hasil akurasinya yaitu 0.6548 untuk pengenalan pola huruf alif ( a ).

Tabel 1. Hasil Pengujian Sistem

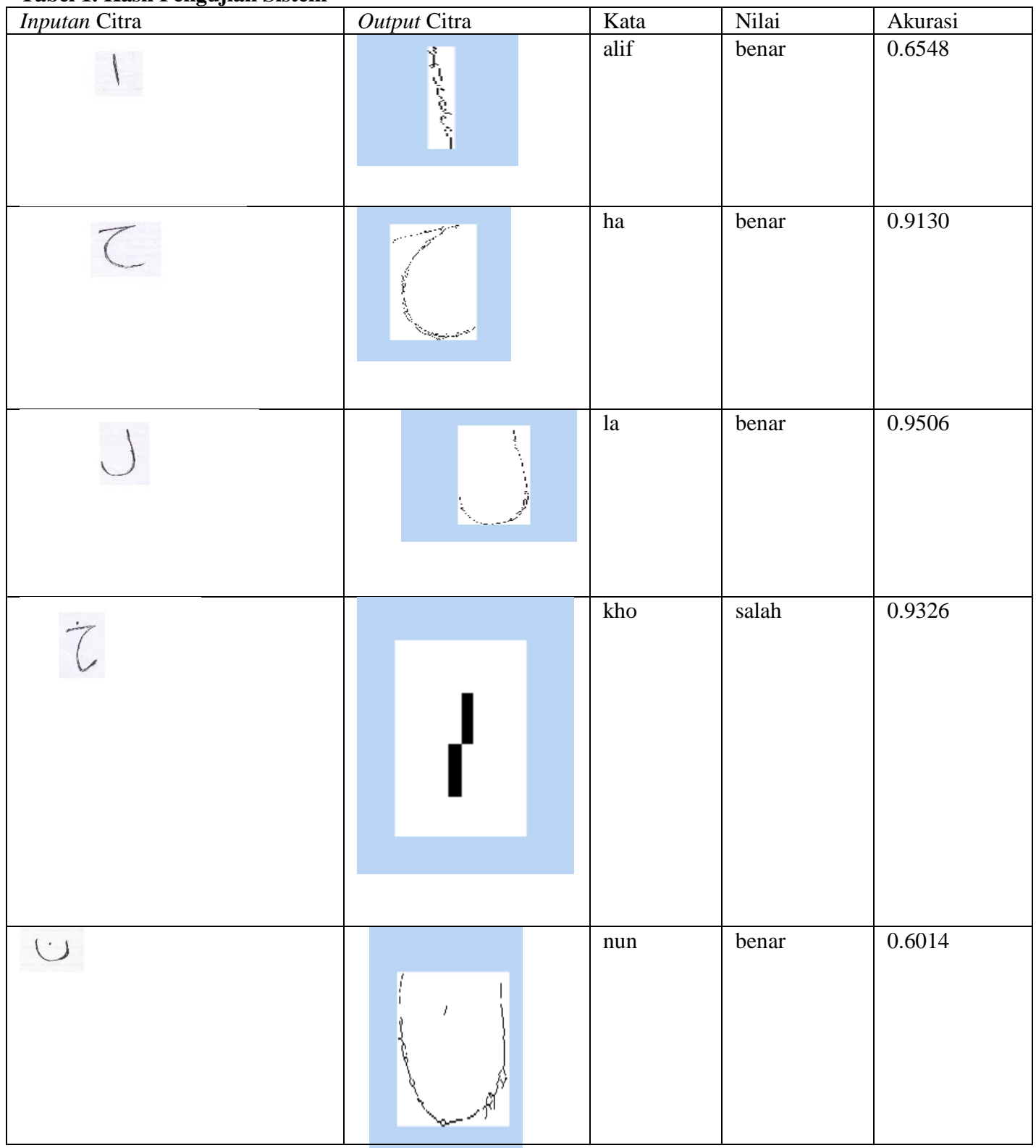

Dari hasil pengujian sistem yang dilakukan, nilai akurasi citra dipengaruhi oleh bentuk goresan pola pada saat menulis pola huruf arab melayu tersebut dengan tangan. Goresan tersebut akan disesuaikan dengan data training . Jadi akurasi yang dihasilkan oleh model dengan input gambar 64x64 piksel dengan jumlah testing sebanyak 1 kali pada inisial alif ini didapatkan nilai akurasi sebesar $4,12 \%$

\section{KESIMPULAN (11 PT)}

Dari hasil pengujian dengan menggunakan tool software matlab dengan inputan berupa gambar inputan citra Scan tulisan aksara salah satu arab melayu, dapat dihasilkan bahwa metode Convolutional Neural Network (CNN) dapat mengenali dengan baik untuk proses ekstraksi citra objek hasil inputan tulisan aksara yang dituliskan berdasarkan kekontrasan goresan tulisan Aksara Arab melayu yang dituliskan di secarik kertas. Untuk kedepannya diharapkan dengan camera sebagai pemindai tulisan dan penggabungan konsonan ditambah dengan pengenalan pengucapan voice recognation untuk pengenalan lebih lanjut. Hasil dari akurasi testing yang dihasilan pada pembelajran training huruf Alif pada satu kali goresan training didapatkan nilai akurasi 4.12 yang mendekati dari hasil inputan matrik 64x64 piksel gambar

\section{UCAPAN TERIMA KASIH}

Penulis mengucapkan terima kasih kepada LLDIKTI dan Universitas Pasir Pengaraian yang telah mendanai penelitian dalam tahun 2020

\section{REFERENSI}


[1] E. Roza, "Aksara Arab-Melayu di Nusantara dan Sumbangsihnya dalam Pengembangan Khazanah Intelektual," TSAQAFAH, 2017, doi: 10.21111/tsaqafah.v13i1.982.

[2] E. Roza and Y. Yasnel, "PENETRASI ISLAM DALAM PENDIDIKAN KEAGAMAAN MASYARAKAT MELAYU DI ROKAN HULU,” POTENSIA J. Kependidikan Islam, 2017, doi: 10.24014/potensia.v3i2.3446.

[3] G. Gunawan, "BENTUK DAN FUNGSI KATEGORI FATIS DALAM KOMUNIKASI LISAN BAHASA MELAYU DIALEK SUNGAI ROKAN,” J. Pendidik. ROKANIA, 2020, doi: 10.37728/jpr.v5i1.272.

[4] M. T. Stefanus Christian Adi Pradhana, Untari Novia Wisesty S.T.,M.T., Febryanthi Sthevanie S.T., "Pengenalan Aksara Jawa dengan Menggunakan Metode Convolutional Neural Network," $e$ Proceeding Eng., 2020.

[5] A. Coates, H. Lee, and A. Y. Ng, "An analysis of single-layer networks in unsupervised feature learning," 2011.

[6] I. Goodfellow, Y. Bengio, and A. Courville, Deep Learning (Adaptive Computation and Machine Learning series). 2016.

[7] E. Herniti, "Islam dan Perkembangan Bahasa Melayu," J. Lekt. Keagamaan, 2018, doi: 10.31291/jlk.v15i1.516.

[8] P. Devikar, "Transfer Learning for Image Classification of various dog breeds," Int. J. Adv. Res. Comput. Eng. Technol., 2016.

[9] T. Zhi, L. Y. Duan, Y. Wang, and T. Huang, "Two-stage pooling of deep convolutional features for image retrieval," 2016, doi: 10.1109/ICIP.2016.7532802.

[10] M. B. Bejiga, A. Zeggada, A. Nouffidj, and F. Melgani, "A convolutional neural network approach for assisting avalanche search and rescue operations with UAV imagery," Remote Sens., 2017, doi: $10.3390 / \mathrm{rs} 9020100$.

[11] A. Krizhevsky et al. "ImageNet Classification with Deep Convolutional Neural Networks Alex," Proc. 31st Int. Conf. Mach. Learn., 2012, doi: 10.1007/s13398-014-0173-7.2. 